\title{
Scrotal hemangiosarcoma in a Large White boar
}

\author{
Renato Luiz Silveira' ${ }^{1,3}$ (D) Ana Claudia de Menezes Cruz $^{2}$ (D) Phillipe Bauer de Araújo Doria ${ }^{3}$ (D) \\ Joao Marcelo Silva Silveira ${ }^{3}$ (i) Carlos Otávio de Paula Vasconcelos ${ }^{3}$ (D) \\ André Luis Rios Rodrigues ${ }^{3}$ (D) Eduardo Kenji Nunes Arashiro ${ }^{4}$ (i) Hassan Jerdy (iD $^{5}$ \\ Mariana Tavares Dias ${ }^{6}$ (D) Eulógio Carlos Queiroz de Carvalho ${ }^{5}$ (D) Carlos Henrique Campello Costa ${ }^{7}$
}

'Departamento de Morfologia (MMO), Universidade Federal Fluminense (UFF), 24210-130, Niterói, RJ, Brasil. E-mail: renatosilveira@id.uff.br. "Corresponding author.

${ }^{2}$ Núcleo de Animais de Laboratório (NAL), Universidade Federal Fluminense (UFF), Niterói, RJ, Brasil.

${ }^{3}$ Departamento de Patologia e Clínica Veterinária (MCV), Universidade Federal Fluminense (UFF), Niterói, RJ, Brasil.

${ }^{4}$ Faculdade de Medicina Veterinária (CMV), Universidade Federal Fluminense (UFF), Niterói, RJ, Brasil.

${ }^{5}$ Programa de Pós-graduação em Ciência Animal (PGA), Universidade Estadual do Norte Fluminense Darcy Ribeiro (UENF), Campos dos Goytacazes, RJ, Brasil.

${ }^{6}$ Gerência Estadual de Bovinocultura, EMATER-RIO, Niterói, RJ, Brasil.

${ }^{7}$ Laboratório de Anatomia Patológica, Centro Estadual de Pesquisa em Sanidade Animal, PESAGRO-RIO, Niterói, RJ, Brasil.

ABSTRACT: Tumors are rarely diagnosed in swine specie because of the short lifespan of production animals. Normally, these tumors do not present any clinical signs and are often detected at the time of slaughter. A 2-year-old Large White boar, used in the reproductive management of a farm and without a history of pre-existing problems, was examined for skin lesions on the scrotum. Samples were collected from skin segments containing lesions for histopathological and immunohistochemical diagnosis. Microscopically, the nodes in the scrotum pouch consisted of poorly demarcated, highly cellular, expansile, and multifocally invasive neoplasms, composed of immature endotheliocytes organized into neovascular formations. The tumor cells were pleomorphic, slightly oval to spindle-shaped, with eosinophilic cytoplasm and hyperchromatic nuclei with one to three nucleoli. All the nodules analyzed were compatible with hemangiosarcoma. After immunohistochemical evaluation, for the quantification of tissue angiogenesis the neoplastic cells immunoexpressed the CD31 monoclonal antibodies and factor VIII, through the identification of proteins expressed on the surface of endothelial cells. The Ki67 cell proliferation marker was positive in approximately 10\% of the neoplastic cells, demonstrating a high degree of malignancy. Hemangiosarcoma in swine species has already been identified in several organs and tissues; however, to date, no study has demonstrated the diagnosis of this condition on the skin of the scrotum, as reported in this study. Therefore, it is expected that this report will contribute to the knowledge of the frequency of neoplasms in swine species.

Key words: hemangiosarcoma, swine, tumor.

Hemangiossarcoma na bolsa escrotal de um reprodutor Large White

RESUMO: Na espécie suína os tumores são pouco diagnosticados devido a curta vida útil dos animais de produção. Normalmente não causam sinais clinicos, sendo, muitas vezes, encontrados no momento do abate. Um reprodutor com dois anos de idade, da raça Large White, utilizado no manejo reprodutivo de uma granja, sem histórico de problemas pré-existentes, foi examinado em função de lesões na pele da bolsa escrotal. Foram coletadas amostras de segmentos de pele contendo lesões para o diagnóstico histopatológico e imunohistoquímico. Microscopicamente os nodos em bolsa escrotal consistiam em neoplasias mal demarcadas, altamente celulares, expansivas e multifocalmente invasivas composta por endoteliócitos imaturos organizados em formações neovasculares. As células tumorais eram pleomórficas, levemente ovais a fusiformes com citoplasma eosinofilico e núcleos hipercromáticos e com um a três nucléolos. Todos os nódulos analisados foram compativeis com hemangiossarcoma. Para a quantificação da angiogênese tecidual, após a avaliação imunohistoquímica, as células neoplásicas imunoexpressaram os anticorpos monoclonais CD31 e Fator VIII, através da identificação de proteinas expressas na superficie das células endoteliais. Observou-se o marcador de proliferação celular Ki67 positivo em aproximadamente 10\% das células neoplásicas, demonstrando um alto grau de malignidade. O hemangiossarcoma na espécie suina já foi identificado em vários órgãos e tecidos, mas, até o momento, nenhum trabalho demonstrou o diagnóstico na pele da bolsa escrotal, como reportado, ineditamente, neste estudo. Face o exposto, espera-se que este relato contribua para a frequência de neoplasias encontradas na espécie suína.

Palavras-chave: hemangiossarcoma, suino, tumor.

Neoplasia is a new growth, composed of cells originally derived from normal tissues. These cells undergone inherited genetic changes and become relatively unresponsive to normal growth controls
(KUSEWITT \& RUSH, 2009). In the porcine species, neoplasia is probably caused by the interaction of infectious, hereditary, and environmental factors (ALSOP, 2005). 
Scrotum neoplasms, such as mastocytoma, melanoma, and hemangiosarcoma, are observed more commonly in dogs. Tumors in this region are rare in other domestic species, have great potential for malignancy, and are usually associated with an unfavorable prognosis (NASCIMENTO et al., 2011).

Tumors are rarely diagnosed in swine specie because of the short life span of production animals. Usually, these tumors do not present any clinical signs and are often detected at the time of slaughter (ROBINSON \& LOYNACHAN, 2019; PEREIRA et al., 2020). Moreover, since necroscopic examination is often not performed when animals are found dead, determination of the prevalence of neoplasms in the species is more difficult (ALSOP, 2005).

Since the sows and boars live longer, they are more prone to manifest tumors (RAMOS et al., 2008). Although uncommon, hemangioma and hemangiosarcoma, have been reported in the male genital region (SZCZECH, 1973; WELLS \& MORGAN, 1980; MUNRO et al., 1982; TEANKUM et al., 2008; MORI et al., 2017; PEREIRA et al., 2020).
According to Morés \& Driemeier (2012), the prevalence of neoplasms among slaughtered pigs varies between 20 to 40/million; and therefore, is extremely low. Since there are few reports of these neoplasms, this study was to describe a case of hemangiosarcoma of the scrotum in a Large White boar.

A 2-year-old Large White boar, used in the reproductive management of a pig farm without a history of pre-existing problems, was examined because of lesions on the skin of the scrotum (Figure 1). During physical examination, testicular asymmetry and miliary skin tumor masses ranging from millimeters to $2 \mathrm{~cm}$ were observed. The diagnosis was hemangioma, and because of the age of the animal, bleeding, and constant concern with myiasis, the manager decided to castrate and discard the animal.

The samples were collected from the testicular parenchyma, epididymis, ductus deferens, and skin segments (Figure 1) containing lesions for histopathological (HE) and immunohistochemical (monoclonal antibodies Ki67, CD31 and factor VIII) diagnoses. The skin lesions were multiple, verrucous

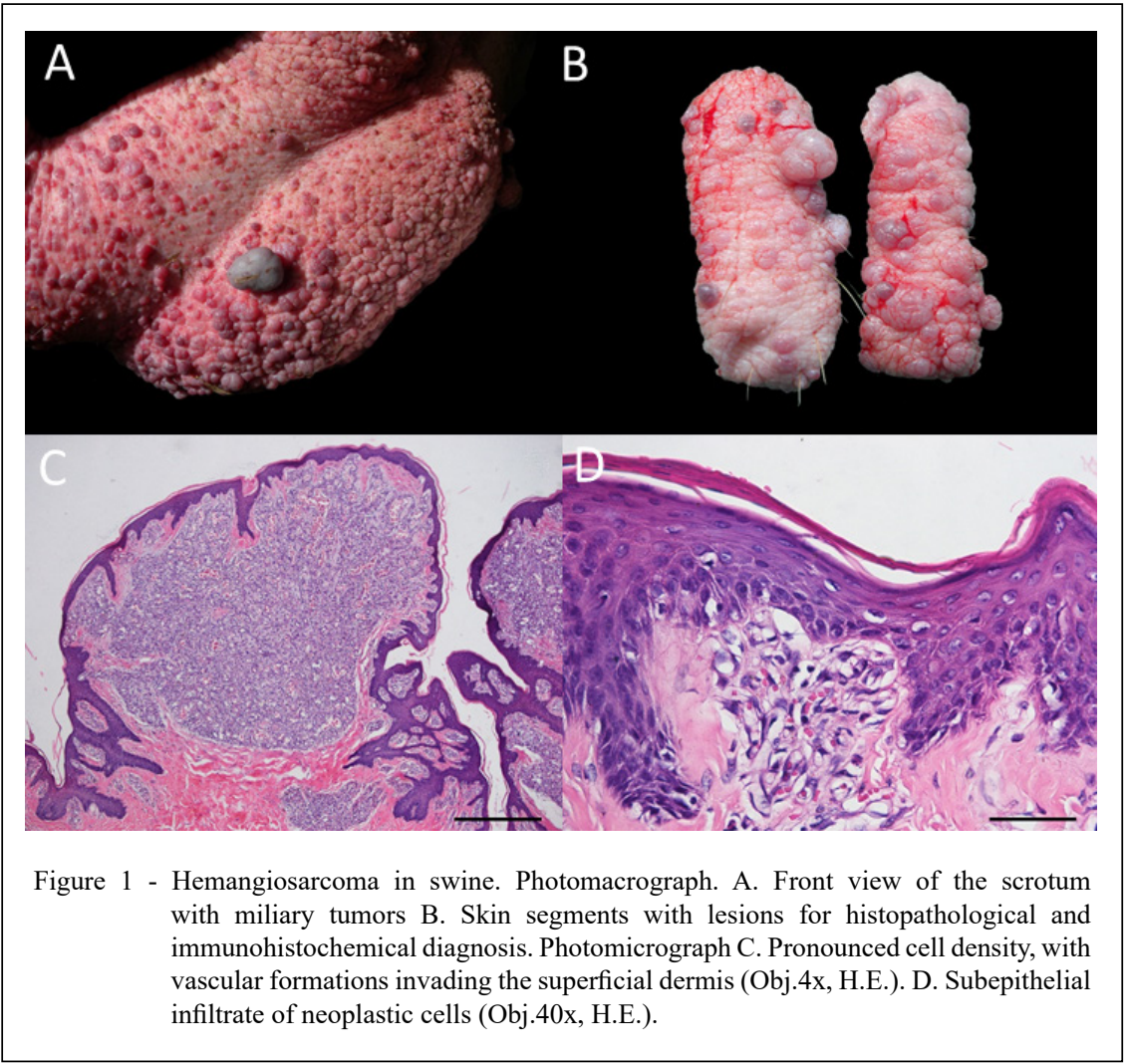

Ciência Rural, v.52, n.4, 2022. 
in appearance, and some were pedunculated. The collected material was stored in identified jars containing neutral buffered formalin and sent to the Histology Laboratory of the Biomedical Institute of the Universidade Federal Fluminense.

After the routine histological processing, no alterations were observed in the testicles, epididymis, or ductus deferens. The skin slides were analyzed in the Laboratory of Pathological Anatomy of the Centro Estadual de Pesquisa em Sanidade Animal of Rio de Janeiro, PESAGRO-RIO. Microscopically, the nodes in the scrotum consisted of poorly demarcated, highly cellular, expansile, and multifocal invasive neoplasms (muscle and superficial and deep dermis) composed of immature endotheliocytes organized in neovascular formations (Figure 1). The tumor cells were pleomorphic, slightly oval to spindle-shaped with eosinophilic cytoplasm and hyperchromatic nuclei with one to three nucleoli (Figure 2). Anisocytosis and anisokaryosis were moderate, with three mitoses per 10 fields of high magnification. All nodules analyzed were compatible with hemangiosarcoma. According to Fubini \& Ducharme (2004), tumors with cellular pleomorphism and mitotic activity are considered hemangiosarcomas.

After immunohistochemical evaluation for the quantification of tissue angiogenesis, the neoplastic cells immunoexpressed the monoclonal antibodies CD31 and Factor VIII (Figure 3), through the identification of proteins expressed on the surface of endothelial cells. The Ki67 cell proliferation marker was positive in approximately $10 \%$ of the neoplastic cells, demonstrating a high degree of malignancy (Figure 2).

The most commonly identified tumors in cardiovascular and hematopoietic systems of swine are lymphoma (BRUM et al., 2015), hemangiosarcoma, hemangioma, and cardiac

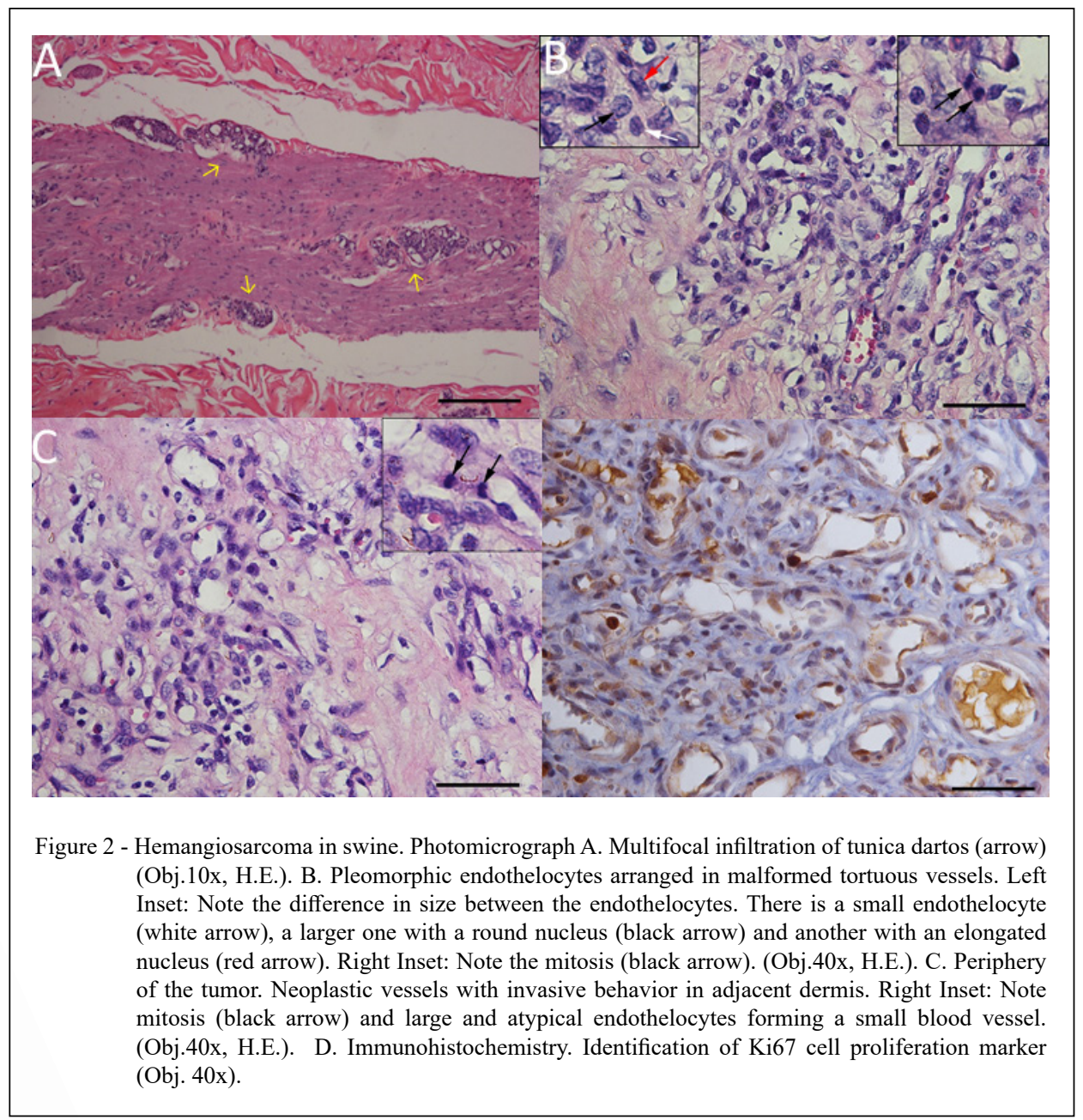

Ciência Rural, v.52, n.4, 2022. 


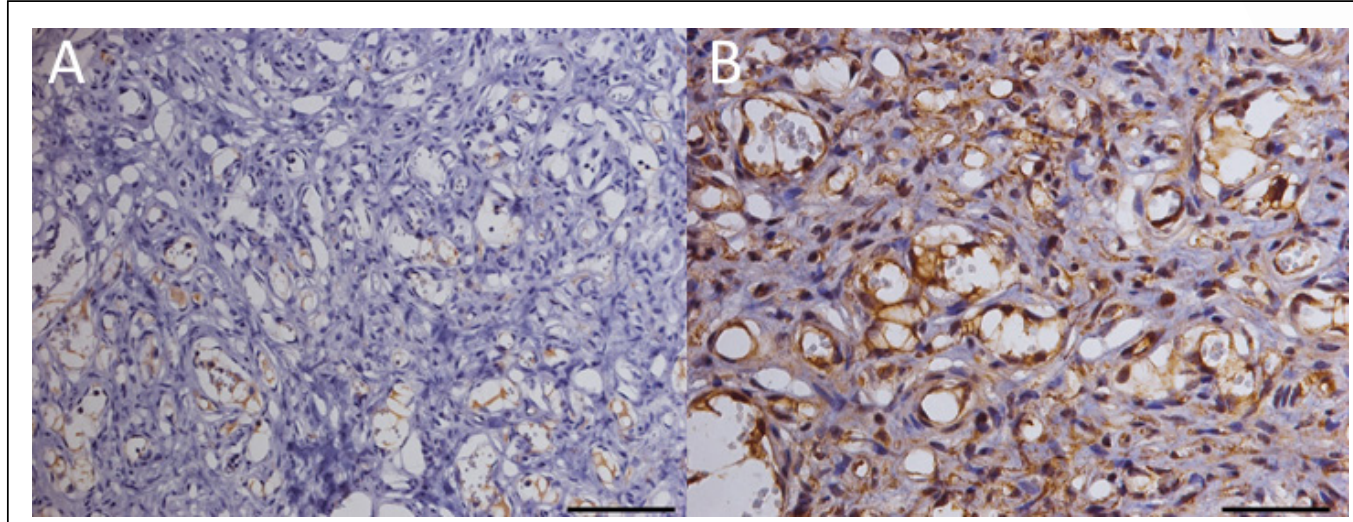

Figure 3 - Hemangiosarcoma in swine. Photomicrograph. Immunohistochemistry of the scrotum skin. A. Identification of CD31 monoclonal antibody (Obj. 20x) B. Identification of the Factor VIII monoclonal antibody (Obj. $40 \mathrm{x})$.

rhabdomyoma (ROBINSON \& LOYNACHAN, 2019). Hemangiosarcoma in swine species has been identified in various organs and tissues such as skin, testis, ovary, liver, spleen, and meninges (FISHER \& OLANDER, 1978; TOSAKA et al., 1999; MORROW, 2002; SPITZBARTH et. al., 2011; MORI et al., 2017) However, to the best of our knowledge, this is the first study to demonstrate this condition on the skin of the scrotum. Although, hemangiosarcoma has already been identified in the testis (FISHER \& OLANDER, 1978), this was not confirmed in this study, since despite testicular asymmetry, no tissue changes were identified. MORÉS \& DRIEMEIER (2012) reported that the presence of hemangiomas in the scrotal region of boars usually occurs between 1 and 4 years of age, and that it has no influence on libido, litter size, and return to estrus. In this study, despite the diagnosis of hemangiosarcoma, the same was observed in boars, both with respect to age and reproductive performance.

Therefore, it is expected that this report will contribute to the knowledge of the frequency of neoplasms reported in swine species.

\section{ACKNOWLEDGEMENTS}

To the Coordenação de Aperfeiçoamento de Pessoal de Nível Superior (CAPES), Brasil.

\section{DECLARATION OF CONFLICT OF INTERESTS}

The authors declare no conflict of interest. The founding sponsors had no role in the design of the study; in the collection, analyses, or interpretation of data; in the writing of the manuscript, and in the decision to publish the results.

\section{AUTHORS' CONTRIBUTIONS}

The authors contributed equally to the manuscript.

\section{BIOETHICS AND BIOSSECURITY COMMITTEE APPROVAL DECLARATION}

We authors of the article entitled "Scrotal Hemangiosarcoma in a Large White boar" declared, for all due purposes, the project that gave rise to the present data of the same has not been submitted for evaluation to the Ethics Committee of the Fluminense Federal University, but we are aware of the content of the Brazilian resolutions of the National Council for Control of Animal Experimentation - CONCEA "http://www.mct.gov.br/index.php/content/ view/310553.html" if it involves animals. Thus, the authors assume full responsibility for the presented data and are available for possible questions, should they be required by the competent authorities.

\section{REFERENCES}

ALSOP, J. E. Lymphosarcoma in three pigs in a multiple-site production system in Ontario. Journal of Swine Health and Production, n.13, v.1, p.31-33, 2005. Available from: <https:// www.aasv.org/shap/issues/v13n1/v13n1p31.html>. Accessed: Dec. 15, 2020.

BRUM, J. S. et al. Neoplasms in swine: 37 casos. Pesquisa Veterinária Brasileira, v.35, n.6, p.541-546, 2015. Available from: <https://www.scielo.br/j/pvb/a/NFwj8JH7LtqjMVydXh MK54t/?format $=$ pdf\&lang=pt $>$. Accessed: Dec. 10, 2020. doi: 10.1590/S0100-736X2015000600009.

Ciência Rural, v.52, n.4, 2022. 
FISHER, L. F.; OLANDER, H.J. Spontaneous neoplasms of pigs: a study of 31 cases. Journal of Comparative Pathology, v.88, n.4, p.505-517, 1978. Available from: <https://www.sciencedirect. com/science/article/abs/pii/002199757890004X?via\%3Dihub>. Accessed: Dec. 15, 2020. doi: 10.1016/0021-9975(78)90004-X.

FUBINI, S; DUCHARME, N. Farm animal surgery. St. Louis, Elsevier, 2004, 597pp.

MORROW, J. L. Hepatocellular carcinoma and suspected splenic hemangiosarcoma in a potbellied pig. Canadian Veterinary Journal, v.43, n.6, p.466-468, 2002. Available from: <https://www.ncbi.nlm.nih.gov/pmc/articles/PMC339301/ pdf/20020600s00021p466.pdf >. Accessed: Jan. 08, 2021.

KUSEWITT, D. F.; RUSH, L.J. Neoplasia e biologia tumoral. In: MCGAVIN, M.D.; ZACHARY, J.F. Bases da Patologia em Veterinária. Rio de Janeiro: Elsevier Editora Ltda, 2009, p.253-298.

MORÉS, N.; DRIEMEIER, D. Neoplasias. In: SOBESTIANSKY, J.; BARCELlOS, D. Doença dos suínos. Goiânia: Cânone Editorial, 2012, p.787-792.

MORI, A. P. et al. Estudo retrospectivo de neoplasias diagnosticadas em suínos: 32 casos (2001-2017). In: XVIII Congresso Brasileiro de Veterinários Especialistas em Suínos, 2017, Goiânia-GO, Anais, XVIII ABRAVES, 2017.

MUNRO, R. et al. Scrotal haemangioma in boars. Journal of Comparative Pathology, v.92, n.1, p.109-115, 1982 Available from: https://www.sciencedirect.com/science/article/ abs/pii/0021997582900469 Accessed: Feb. 12, 2021. doi: 10.1016/0021-9975(82)90046-9.

NASCIMENTO, E. F. et al. Sistema reprodutivo masculino. In: SANTOS, R.L.; ALESI, A.C. Patologia Veterinária. São Paulo: Roca, 2011, p.855-880.

PEREIRA, P. R. et al. Primary skin diseases and cutaneous manifestation of systemic diseases in swine. Pesquisa Veterinária Brasileira, v.40, n.8, p.579-588, 2020. Available from: $<\mathrm{https}: / /$ www.scielo.br/scielo.php?script=sci_arttext\&pid=S0100-
736X2020000800579>. Accessed: Dec. 28, 2020. doi: 10.1590/1678-5150-pvb-6704

RAMOS, A. T. et al. Tumores em animais de produção: aspectos comparativos. Ciência Rural. v.38, n.1, p.148-154, 2008. Available from: $<$ https://www.scielo.br/j/cr/a/ZhwH77p5zMyc599 Pyz3gY8p/?format=pdf\&lang=pt $>$. Accessed: Dec. 15, 2020. doi: $10.1590 / \mathrm{S} 0103-84782008000100024$

ROBINSON, N. A.; LOYNACHAN, A. T. Cardiovascular and hematopoietic systems. In: ZIMMERMAN, J.J. et al. Diseases of swine. Hoboken: Wiley Blackwell, 2019, p.223-233.

SPITZBARTH, I. et al. Primary meningeal hemangiosarcoma in a grower pig. Journal of Veterinary Diagnostic Investigation, v.3, n.1, p.162-167, 2011. Available from: <https://researchgate.net/ publication/49739098_Primary_Meningeal_Hemangiosarcoma in_a_Grower_Pig $>$. Accessed: Dec. ${ }^{-13}, 2020$. doi: $10.1177 / 10406387110230013210$.

SZCZECH, G.M. et al. Hemangioma of the scrotum in a chester white boar. Canadian Veterinary Journal, v.14, n.1, p. 16-18, 1973. Available from: https://www.ncbi.nlm.nih.gov/pmc/articles/ PMC169599 Accessed: Oct. 11, 2020.

TEANKUM, K. et al. Capillary haemangiomas of the scrotum and testicle in boars. Journal of Comparative Pathology, v.139, n.4, p.177-186, 2008. Available from: <https://www.sciencedirect. com/science/article/abs/pii/S0021997508000807?via\%3Dihub $>$. Accessed: Dec. 07, 2020. doi: 10.1016/j.jcpa.2008.06.005.

TOSAKA, Y. et al. Young swine case hemangiosarcoma in the liver. Journal of the Japan Veterinary Medical Association, v.52, n.4, p.253-255, 1999. Available from: <https://www.jstage. jst.go.jp/article/jvma1951/52/4/52 4 253/ article/-char/en>. Accessed: Dec. 15, 2020. doi: $10.129 \overline{3} 5 / \bar{j}$ vma1951.52.253

WELLS, G.A.H.; MORGAN, G. Multifocal haemangioma in a pig. Journal of Comparative Pathology, v.90, n.3, p.483-490, 1980. Available from: <https://www.sciencedirect.com/science/ article/abs/pii/0021997580900183?via\%3Dihub>. Accessed: Dec. 15, 2020. doi: 10.1016/0021-9975(80)90018-3. 